\title{
PEMBUATAN ALAT PENGERING BERPUTAR (ROTARY) KOPI DAN LADA HITAM MENGGUNAKAN MIKROKONTROLER ARDUINO UNO DESA AIR RAMAN KABUPATEN KEPAHIANG PROPINSI BENGKULU
}

\section{MANUFACTURING OF ROTARY DRYER FOR COFFEE BEAN AND BLACK PEPPER USING MICROCONTROLLER ARDUINO UNO IN THE VILLAGE OF AIR RAMAN KEPAHIANG DISTRICT BENGKULU PROVINCE}

\author{
Oleh: \\ Anizar Indriani ${ }^{1}$, Yovan Witanto ${ }^{2}$, Hendra $^{2}$ \\ ${ }^{I}$ Program Studi Teknik Elektro Fakultas Teknik Universitas Bengkulu \\ ${ }^{2}$ Program Studi Teknik Mesin Fakultas Teknik Universitas Bengkulu
}

Email: aniz_raimin@yahoo.com

\begin{abstract}
Bengkulu Province has many potentials such as beaches, conservation forests, plantations and others. Plantations in Bengkulu consist of smallholders and private / BUMN businesses. Smallholder plantations include coffee, black pepper, palm, rubber, areca nut and other gardens. The results of this plantation are still traditionally processed, which is drying and drying in the open with the help of solar heat. This drying process is still being implemented where the quality is poorly controlled. This has caused the yield of the plantation in Bengkulu to be unknown to other regions. like coffee in the Bengkulu area which has a distinctive taste characteristic compared to other regions. Coffee that is processed is Robusta or Arabica coffee which is the mainstay of the people of Air Raman Village, Bengkulu Province. The processing process is dried in the yard of the house, field, roadside and others. This drying and processing process is easily polluted from dust, animal waste, uneven drying. And the erratic drying time causes the villagers to need a machine or garden processing technology. One technology is a rotary dryer. Rotary drying machines can be used by utilizing regional potential such as solar energy, wind energy, water energy and others. In addition to Coffee, this village also has garden products such as black pepper, Pinang and others where the process is the same as the coffee harvest. The advantage of this dryer is a shorter drying time, the use of solar energy can minimize operational costs for drying coffee and black pepper. The dried coffee and black pepper are free from animal waste, dust and various other types of garbage and the process of drying more than 4 days from drying is done manually / in the public yard. This is because the temperature inside the drying machine is rotary higher than the open air, the level of dryness of coffee and black pepper is produced evenly, because the temperature in the rotary dryer is equipped with a stirrer evenly spread so that the stirring process is no longer necessary. The working mechanism of this tool is expected to help people producing coffee and black pepper to dry their crops so that the quality of coffee and black pepper is good and the selling value is high. The output of PPM activities The application of science and technology is a high selling value that will increase people's income, improve people's welfare to be better and also create new jobs for the community as a producer of rotary
\end{abstract}


drying machines. The availability of appropriate technology for the design and construction of rotary drying machines. Scientific publications at the national level are published in the national journal Dharma Raflesia June 2019.

Keywords: Coffee, Black Pepper, Rotary Dryer, Microcontroller, Service Community

\section{PENDAHULUAN}

Propinsi Bengkulu merupakan daerah yang berada pada bagian pesisir barat pulau Sumatera berbatasan langsung dengan Propinsi Lampung dan Sumatera Barat. Kondisi alam Propinsi Bengkulu hampir mirip dengan kondisi alam di Propinsi Lampung dan Sumatera Barat dimana sumber penghasilan masyarakatnya didapatkan dari hasil perkebunan, pertanian, nelayan dan lainnya. Kekayaan alam dari hasil kebun dan tani serta nelayan yang melimpah di Propinsi Bengkulu masih banyak yang belum terolah secara maksimal dibanding daerah Propinsi lain. Hal ini dapat dilihat dari hasil kebun atau pertanian yang dijual masih dalam kondisi mentah atau setengah jadi dengan harga pasar yang rendah. Proses pengolahan yang masih alami, kondisi alam dan iklim ikut memberikan peranan dalam menurunkan nilai ekonomis produk dan penghasilan masyarakat petani di daerah Propinsi Bengkulu, seperti untuk pengolahan kopi, lada hitam, pinang, dan lainnya yang masih mengandalkan kondisi alam dan iklim dalam proses pengeringannya.

Proses pengolahan kopi, lada hitam dan biji-biji lainnya dilakukan dengan cara dijemur di halaman, di pinggir jalan, dan di area tanah yang luas (seperti terlihat pada Gambar 1) yang mana hal ini sangat mempengaruhi kualitas hasil pengolahannya. Waktu pengolahan yang lama, kualitas mutu K3 yang rendah, produk yang kurang higienis dan sebagainya merupakan satu kendala dalam hal pengolahan secara alami. Sementara tuntutan untuk menghasilkan produk dengan kualitas yang tinggi dalam waktu singkat merupakan suatu keharusan yang mesti dipenuhi, seperti standar K3 (kualitas kadar air), kebersihan hasil pengolahan, dan proses pengolahan yang ramah lingkungan.

Kabutapen Kepahiang termasuk wilayah di Propinsi Bengkulu yang memiliki sumber daya alam melimpah seperti kopi robusta dan arabica, lada, pinang, padi dan hasil pertanian lainnya. Proses pengolahan hasil perkebunan di daerah ini masih dilakukan secara alami memanfaatkan cuaca atau iklim. Potensi alam ini susah untuk diprediksi sehingga hasil pengolahan menggunakan potensi ini kurang maksimal misalnya untuk mengeringkan kopi membutuhkan lebih dari 7 hari untuk proses pengeringannya jika cuaca hujan/mendung. Hal ini sangat merugikan karena penghasilan masyarakat menjadi tidak menentu.

Untuk menanggulangi hal ini dapat digunakan beberapa inovasi-inovasi dan teknologi yang telah diterapkan di berbagai daerah penghasil kopi, lada dan biji-bijian lainnya untuk membuat alat bantu berupa mesin pengolahan hasil panen ramah lingkungan, higienis dan waktu pengolahan yang cepat (Tambunan, 2017), dan (Sutrisno, 2006) dan (Setiawan, 2016). Inovasi ini dikembangkan dengan memanfaatkan beberapa sumber energi seperti energi motor (Setiawan, 2016), energi angin dan surya (Amali, 2015), (Gunasekaran, 2012) dan (Putra, 2013). Beberapa peneliti membuat mesin untuk pengolahan hasil panen menggunakan sumber energi dari kayu, ampas padi atau sumber energi panas dari energi fosil (Anonim, 2009), (Nugraha, 2008) dan (Hermawan, 2009). Mesin pengering yang dibuat dapat berupa mesin pengayak getar, mesin pengering tenaga surya dan mesin pengering dengan sumber energi dari energi angin, energi dari sisa panen seperti cangkang sawit, kelapa dan lainnya. 
Dalam pengabdian masyarakat PPM Penerapan IPTEKS ini digunakan mesin pengering berputar (rotary) untuk proses pengeringan kopi, lada hitam dan biji-biji lainnya. Mesin pengering berputar (rotary) ini memiliki kelebihan yaitu dapat mengeringkan hasil panen dalam waktu singkat, hasil pengeringan yang merata, meningkatkan kualitas produk (kadar air rendah), bersih dan higienis serta proses pengolahan yang ramah lingkungan. Selain itu mesin ini juga mudah dibuat dengan peralatan yang dapat diperoleh dengan mudah, murah dan dari bahan-bahan yang tidak terpakai seperti drum, pelat dan lainnya. Permasalahannya terletak pada kekurangtahuan masyarakat desa dalam membuat dan menggunakan mesin pengering ini. Mesin pengering berputar (rotary) ini bekerja dengan memanfaatkan sumber energi surya), dengan harapan petani dapat menggunakan mesin pengering berputar (rotary) dengan harga produksi yang terjangkau dan murah. Hal ini dilakukan karena petani sangat mudah untuk mendapatkan energi surya di daerah-daerah Bengkulu khususnya Kota Kepahiang.

Untuk meningkatkan kualitas dan mutu pengeringan hasil kebun di Kota Kepahiang ini maka dibuat alat pengering rotari dengan tujuan untuk menghasilkan produk olahan biji-bijian seperti kopi, lada hitam dan lainnya agar memiliki kualitas kadar air dan mutu yang baik serta higienis. Khususnya untuk Desa Air Raman Kecamatan Bermani Ilir, karena pengetahuan masyarakat yang masih rendah dalam membuat suatu alat tepat guna untuk proses pengolahan hasil panen yang dihasilkan seperti kopi, lada dan biji-bijian lainnya. Maka dalam pengabdian masyarakat PPM Penerapan IPTEKS ini dilakukan alih pengetahuan dengan cara pelatihan pembuatan, pemilihan bahan dan penggunaan mesin pengering berputar (rotary) untuk pengolahan hasil panen kopi, lada dan biji-bijian tersebut agar diperoleh produk dengan kualitas baik dan higienis serta memiliki nilai ekonomis produk tinggi. Nilai ekonomis yang tinggi akan berdampak pada pendapatan dan kesejahteraan masyarakat yang juga akan meningkat. Produk yang dihasilkan dalam program kemitraan masyarakat ini adalah mesin pengering berputar (rotary) kopi robusta, kopi arabica dan hasil panen biji-bijian dengan pemanfaatan sumber energi Surya.

Pengolahan hasil panen di daerah Kepahiang khususnya Desa Air Kecamatan Bermani Ilir masih dilakukan secara terbuka dan alamiah dengan mengandalkan kondisi alam dan cuaca/iklim Proses pengolahan ini memiliki beberapa kelemahan yaitu kondisi iklim yang tidak konstan dan temperatur pengeringan tidak merata, membutuhkan area pengolahan yang luas dan tenaga kerja yang selalu harus menunggu dan berada ditempat (lihat Gambar 1c). Hal ini menyebabkan proses pengeringan ini menjadi kurang efektif dan efisien seperti waktu pengeringan yang lama, kualitas/mutu produk hasil pengolahan susah dikontrol, kurang higienis, biaya untuk pengolahan menjadi tinggi dan harga jual rendah. Nilai jual atau ekonomis produk yang rendah menyebabkan pendapatan masyarakat juga menjadi rendah. Dimana mayoritas penghasilan masyarakat desa ini adalah berkebun kopi, lada dan biji-bijin lainnya. 


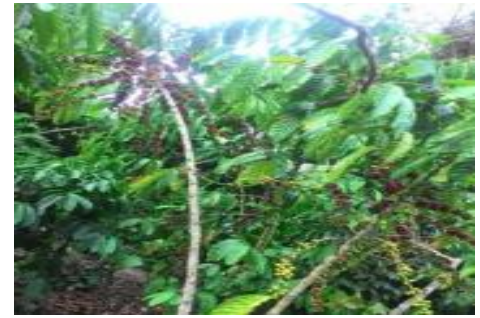

a. Kopi

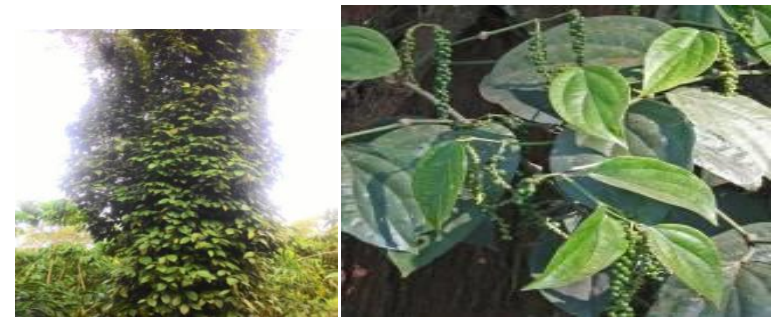

b. Lada Hitam
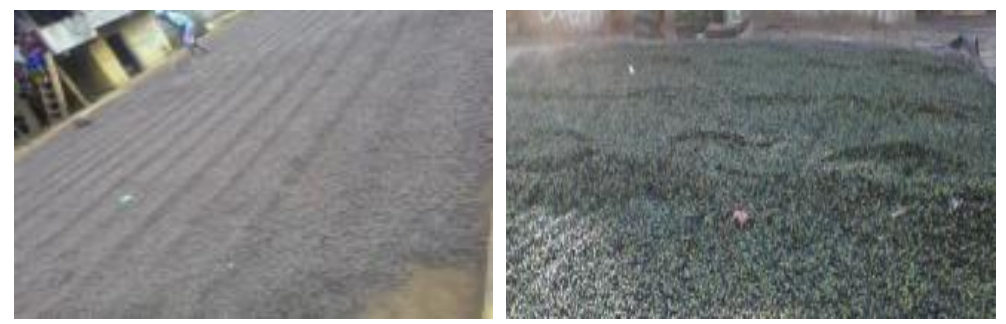

c. Proses Pengeringan Kopi dan Lada Hitam di Halaman

Gambar 1. Pohon Kopi, Lada hitam dan proses pengeringan Kopi dan Lada

Pembuatan mesin pengering berputar (rotary) bagi masyarakat penghasil kopi, lada hitam dan lainnya akan terbantu dalam mengolah hasil panen mereka, karena alat tepat guna ini akan dapat membantu mempercepat waktu pengolahan hasil panen, menjaga kualitas K3 hasil panen dan kebersihan produk. Proses penggunaan mesin pengering rotari yang sederhana dapat dilakukan dirumah oleh kaum ibu (perempuan) atau masyarakat dalam area yang tidak begitu luas sambil tetap beraktifitas sehari-hari dirumah. Desa Air Raman Kecamatan Bermani Ilir Kabupaten Kepahiang, pada waktu pagi hingga siang hari sering ditemui ibu-ibu atau kaum perempuan serta pemuda putus sekolah yang bekerja dirumah untuk menjemur kopi, lada dan hasil kebun lainnya. Sistem kerja mesin pengering ini juga memanfaatkan sistem kontrol mikrokontroler arduino uno untuk proses pengaturan temperatur dan penggerak mesin pengering.

Tata kelola perancangan, pembuatan dan pemeliharaan mesin pengering berputar (rotary) berbasis mikrokontroler Arduino Uno serta penggerak alat penggering menggunakan tenaga surya akan diberikan pelatihan pada pemuda putus sekolah secara periodik dan terstruktur. Penggunan sistem kontrol sederhana tentang alat pengering berputar (rotary) juga dilatih pada pemuda putus sekolah untuk membekali softskill pada pemuda putus sekolah. Pada kaum ibu- ibu dan bapak-bapak yang usia lanjut masyarakat pengahasil kopi dan lada hitam akan dilatih penggunaan dan pemeliharaan mesin pengering berputar (rotary).

Dengan mesin pengering berputar (rotary) ini kaum ibu atau masyarakat akan sangat terbantu dalam bekerja sehari-hari dan juga mesin pengering berputar ini mudah dibuat, sederhana, ringan dan mudah dioperasikan. Proses pengeringan yang cepat dan menggunakan enegi surya yang mudah diperoleh oleh masyarakat.

Tujuan pengabdian masyarakat PPM Penerapan IPTEK adalah untuk alih teknologi dan pengetahuan tentang mesin pengering rotari dan sistem kerjanya kepada masyarakat desa penghasil kopi, lada hitam atau pinang. Alih teknologi dan pengetahuan ini 
dilakukan dengan cara memberi pelatihan tentang rancangan dan komponen mesin pengering rotari dengan sistem kontrol arduino uno dan cara penggunaannya. Meningkatkan pengetahuan masyarakat tentang pemanfaatan mesin pengering rotari dan sistem kontrolnya dalam mengolah hasil perkebunan sehingga dapat meningkatkan kualitas dan mutu hasil kebun berupa kopi, lada hitam atau pinang.

\section{Faktor Yang Mempengaruhi Pengeringan}

Prinsip pengeringan biasanya akan melibatkan dua kejadian yaitu : (1) panas harus diberikan pada bahan yang akan dikeringkan, dan (2) air harus dikeluarkan dari dalam bahan. Dua fenomena ini menyangkut pindah panas ke dalam dan pindah massa keluar. Pindah massa adalah pemindahan air keluar dari bahan komoditi. Faktor-faktor yang mempengaruhi dalam kecepatan pengeringan adalah :

1. Luas permukaan

2. Perbedaan suhu sekitar

3. Kecepatan aliran udara

4. Tekanan Udara

Selain beberapa faktor diatas, kelembaban udara juga berpengaruh besar terhadap pengering biji kopi ini. Secara umum, kelembaban udara adalah ukuran kandungan air di udara. Kelembaban udara dapat dinyatakan dalam dua pengertian yang berbeda yaitu kelembaban mutlak dan kelembaban relatif. Kelembaban mutlak adalah massa uap air dalam tiap satuan massa udara kering., dinyatakan oleh satuan massa uap air per satuan massa udara kering. Tingkat kejenuhan udara dinyatakan oleh relative humidity (RH). Jelasnya, RH adalah perbandingan kelembaban udara tertentu dengan kelembaban udara jenuh pada kondisi tekanan dan temperatur yang sama. Perbandingan ini dinyatakan dalam persentasi kejenuhan dengan $100 \%$ RH untuk udara jenuh dan $0 \%$ untuk udara yang bebar-benar kering. Sistem pengeringan membutuhkan media pengeringan atau mesin pengolahan untuk mempercepat hasil pengeringan.

Permasalahan yang timbul pada proses pengolahan hasil panen adalah pada media pengolahan atau mesin pengolahnya. Media yang sering digunakan masih alamiah memanfaatkan lingkungan dan iklim serta kondisi alam seperti menjemur di area yang luas, dipinggir jalan, di lapangan yang banyak ternak dan area lainnya. Iklim dan kondisi alam yang tidak menentu dapat mempengaruhi kualitas produk seperti musim hujan, mendung, angin kencang dan lainnya. Hal ini menjadi kendala pada saat proses pengeringan (Henderson dan Perry, 1990) hasil panen. Dimana pengaruhnya adalah kualitas produk pengeringan yang rendah, tidak higienis dan bersih sehingga harga jualnya menjadi murah dan pendapatan masyarakat menjadi terganggu dan menurun. Untuk menjaga kualitas hasil pengeringan dan meningkatkan pendapatan masyarakat daerah itu maka dilakukan alih teknologi melalui pelatihan dalam merancang, membuat, memilih dan menggunakan mesin pengering rotary yang sederhana, mudah dibuat dan dioperasikan untuk mengolah hasil kebun sehingga memiliki nilai jual yang tinggi.

Proses pengolahan hasil panen yang dibuat adalah proses pengeringan dengan memanfaatkan energi surya untuk menggerakan komponen pemanas dimana panas yang diperoleh dialirkan ke dalam pipa pengalir dan drum pengering. Proses pengolahan hasil panen dengan mesin ini sangat sederhana dan hasil yang diperoleh lebih baik dibanding dengan proses pengeringan alami.

Proses pengenalan komponen dan cara kerja mesin pengering rotary adalah:

\section{Kontruksi Mesin pengering rotary}


Pengering rotary memiliki beberapa komponen seperti tungku pembakaran, drum pengeringan, pipa saluran uap panas, rangka/kontruksi, poros pemutar drum pengeringan dan sirip-sirip pengaduk seperti dapat dilihat pada Gambar 2.

Komponen pengering rotary terdir atas :

1. Drum pengeringan

Drum pengeringan digunakan sebagai tempat pengeringan bahan hasil panen yang terbuat dari pelat baja yang diroll berbentuk tabung silinder. Dimana pada bagian dalam drum pengeringan terdapat sirip-sirip pengaduk dan poros pengalir aliran panas dari tungku pembakaran.

2. Pipa pengalir uap panas

Pipa pengalir uap panas berbentuk pipa yang dilubangi untuk meneruskan uap panas dari tungku pembakaran (lihat Gambar 2).

3. Rangka dudukan mesin pengering rotary (lihat Gambar 2).

4. Kincir angin sebagai pengaktif elemen pemanas pada bagian dalam pipa pengalir uap panas pada mesin pengering rotary.

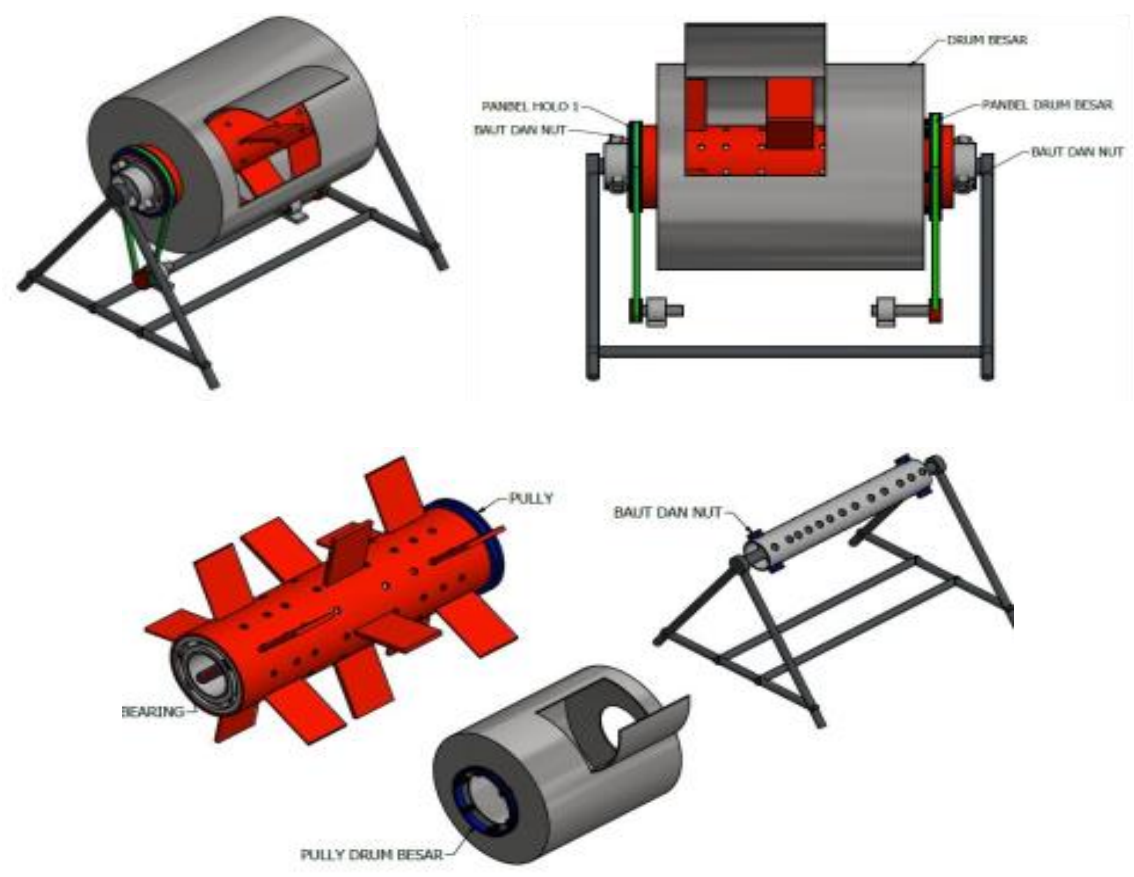

Gambar 2. Mesin pengering rotary (Pengering rotary)

\section{Sistem kontrol proses pengering.}

Sistem kontrol proses pengering dapat menggunakan PLC, mikrokontroller dan sistem lainnya. Dalam pengabdian masyarakat PPM Penerapan IPTEKS ini menggunakan mikrokontroler arduino uno, dimana sistem kontrol ini berfungsi untuk mengatur sistem pemanasan, temperatur pemanasan dan komponen penggerak pada mesin pengering rotari.

\section{Prinsip Kerja Alat Pengering}

Pengering rotary terdiri dari beberapa komponen utama yaitu drum pengering (tabung silinder), kincir angin, dan kerangka dudukan drum pengering (tabung silinder). 
Dalam drum pengering terdapat pipa pengalir udara panas dan sirip-sirip pengaduk dan perata bahan yang akan dikeringkan. Pipa pengalir udara panas berfungsi untuk pengalir panas yang diperoleh dari elemen pemanas dengan energi kincir angin dan akan dialirkan ke hasil panen yang akan dikeringkan.

\section{METODE PENGABDIAN}

Metode pelaksanaan pengabdian masyarakat adalah berdasarkan analisis situasi serta kondisi masyarakat (terutama kondisi mitra), maka ada 4 (empat) metode pendekatan yang dapat digunakan agar penyelesaian masalah dapat berjalan dengan baik dan benar. Metode yang ditawarkan adalah:

\section{Metode Penyuluhan.}

Kegiatan penyuluhan dimaksudkan untuk membuka wawasan berpikir serta pengetahuan secara teori kepada peserta. Materi yang disampaikan yaitu :

- Teknik penaganan kopi dan lada hitam yang baik dan benar.

- Desain dan konstruksi alat pengering berputar (rotary) dan pembuatan Energi Surya sebagai penggerak pemanas.

- Pengontrolan sistem pengering menggunakan mikrokontroler arduino uno.

Materi penyuluhan akan diberikan juga secara tertulis kepada peserta. Setelah selesai ceramah, dilanjutkan dengan diskusi antar peserta dan narasumber. Kegiatan penyuluhan dilakukan selama 1 (satu) hari dengan mempertimbangkan waktu yang tepat agar seluruh anggota kelompok mitra dapat hadir.

\section{Demontrasi.}

Kegiatan ini dilakukan oleh narasumber dibantu teknisi dan mahasiswa serta disaksikan oleh peserta. Kegiatan ini dimaksudkan untuk memberi gambaran, petunjuk dan pemahaman secara lebih jelas tentang bagaimana pemecahan persoalan yang dihadapi oleh peserta. Tahapan kegiatan demonstrasi yang dilakukan meliputi:

- Cara mendesain alat pengering berputar (rotary) dan cara menempatkan alat berdasarkan posisi yang tepat. Kegiatan dilakukan secara langsung dengan kelompok mitra selama 2 hari.

- Cara pemilihan bahan drum pengering berputar (rotary).

- Cara penggunaan sistem kontrol mikrokontroler Arduino Uno.

- Cara penggunaan tenaga surya sebagai penggerak sistem pemanas pada mesin berputar (rotary).

\section{Pelatihan.}

Kegiatan pelatihan dimaksudkan untuk memberikan kesempatan kepada kelompok mitra untuk menambah keterampilan terlatih untuk memecahkan persoalan yang mungkin dihadapi. Kegiatan pelatihan meliputi beberapa tahap:

\section{a. Pelatihan pengenalan komponen mesin pengering rotary.}

Pengering rotary memiliki beberapa komponen yang dapat dilihat pada Gambar 3, seperti Panel surya, drum pengeringan, pipa saluran udara panas, rangka/kontruksi, poros pemutar drum pengeringan dan sirip-sirip pengaduk.

Komponen pengering rotary terdiri atas :
a) solar cell
b) Drum pengeringan
c) Sirip-sirip Pengaduk
d) Poros pengalir udara panas
e) Rangka dudukan mesin pengering rotary rotary. 

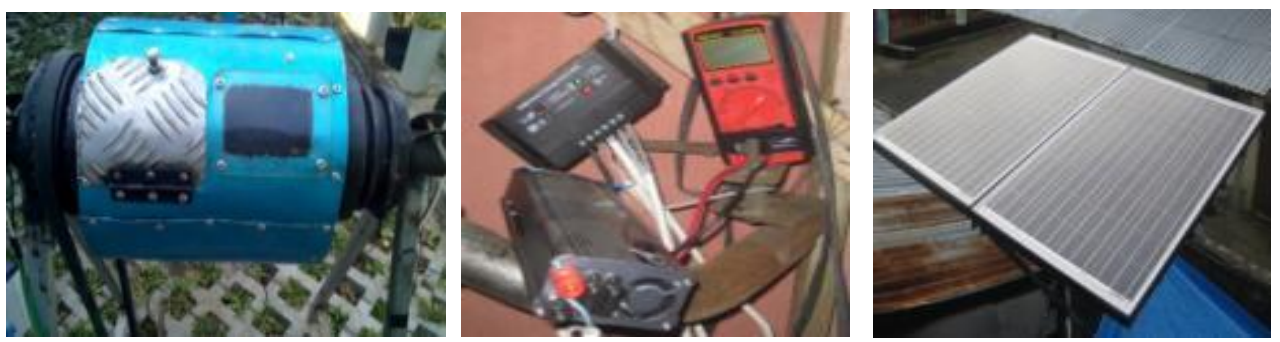

Gambar 3. Mesin Pengering Rotari, Kontroller dan Panel Surya

Proses pelatihannya adalah dengan menjelaskan dan memberi contoh komponen mesin pengering rotary dan bahan yang sesuai seperti : Panel surya, Pipa pengalir panas, Pipa buang, Drum pengering, Motor penggerak mesin pengering rotary, Roda gigi dan rantai, Rangka mesin pengering rotary serta bantalan.

b. Pelatihan perancangan, pemilihan bahan dan pembuatan alat pengering hasil kebun berupa kopi dan lada hitam

Prosedur pelatihan ini meliputi:

a) Perancangan, pemilihan bahan dan pembuatan mesin pengering rotary hasil perkebunan dan hasil hutan.

b) Pengujian mesin pengering rotary dengan pemaanfaatan hasil panen petani (kopi robusta dan arabica), lada hitam menggunakan filamen pemanas memanfaatkan energi angin melalui kincir angin.

c. Pelatihan Prosedur kerja mesin pengering rotary.

Pelatihan prosedur kerja mesin pengering rotary yang dibuat adalah:

a) Mempersiapkan semua alat dan komponen pengering rotari.

b) Mempersiapakan elemen pemanas.

c) Hasil panen seperti kopi dimasukan dalam drum pengering.

d) Putar drum pengering hingga panas merata di dalam tabung silinder.

e) Panaskan hasil panen selama beberapa jam (tergantung berat hasil panen yang akan dikeringkan) dan ukur kadar air yang hasil panen tersebut.

Rencana Kegiatan yang menunjukkan langkah-langkah penerapan Program Kemitraan Masyarakat di desa Air Raman Kecamatan Bermani Ilir Kabupaten Kepahiang dengan melibatkan 15 orang dengan berbagai tahapan sebagai berikut:

\section{a. Tahapan Rencana tindakan}

Penerapan teknologi ini menggunakan metode pendekatan pelatihan campuran. tahap pertama dengan menggunakan teknik inovasi dan kreatifitas membuka wawasan pengetahuan masyarakat akan mesin pengering berputar (rotary) yang ramah lingkungan, mudah dibuat dengan harga terjangkau dan aplikasi dari mesin pengering berputar (rotary) serta sumber energi yang digunakan. Tahap kedua dengan menggali kemampuan dasar masyarakat dalam proses perencanaan dan pembuatan mesin pengering berputar (rotary). Tahap selanjutnya adalah membuat dan menguji mesin pengering berputar (rotary) agar langsung menghasilkan produk dengan kualitas pengeringan yang baik, waktu pengeringan yang cepat dan higienis. Serta diakhiri cara melakukan perawatan/pemeliharaan alat agar dapat digunakan dalam waktu yang lama. Subjek penelitian dalam hal ini adalah masyarakat Kelompok Tani penghasil kopi dan lada hitam di Desa Air Raman Kecamatan Bermani Ilir. 
Kabupaten kepahiang Propinsi Bengkulu. Langkah-langkah kegiatan yang dilakukan adalah sebagai berikut:

1. Kegiatan ini diawali dengan diskusi antara pendamping pelatihan dengan pemuka masyarakat (Kepala Desa, Sekretaris Desa dan masyarakat petani).

2. Pendamping melakukan interview peserta untuk mengetahui wawasan mereka tentang proses pengolahan hasil kebun berupa kopi dan lada hitam dan aplikasi penggunaan mesin pengering berputar (rotary).

3. Pendamping memberi pengarahan dan materi tentang proses perancangan, pembuatan dan penggunaan mesin pengering berputar (rotary) untuk pengolahan Kopi Robusta dan Arabica serta lada hitam.

4. Berdasarkan data hasil interview dan pengamatan sebelumnya dilakukan diskusi tentang pemahaman peserta pelatihan tentang proses pembuatan dan penggunaan mesin pengering berputar (rotary) untuk pengolahan kopi dan Lada Hitam.

5. Pendamping dan peserta berdiskusi rencana keterampilan untuk pertemuan berikutnya.

6. Pendamping memberi teori tentang mesin pengering berputar (rotary) dan komponen-komponennya untuk pengolahan kopi robusta, kopi arabica dan lada hitam serta mempraktekkan teori-teori tersebut.

7. Pendamping memberi kesempatan para peserta untuk membuat mesin pengering berputar (rotary) secara berkelompok dan individu.

8. Pendamping mengamati kemampuan yang telah dimiliki peserta.

9. Menetapkan keberhasilan tahapan awal dalam bereksperimen.

\section{b. Tahapan Pelaksanaan Tindakan}

1. Pada tahap pelaksanaan lanjutan dimulai dengan pemberian materi dan informasi tentang aplikasi mesin pengering berputar (rotary) menggunakan energi surya, komponen pemanas, pemilihan bahan dan proses pembuatan serta permasalahan yang sering timbul pada saat membuat dan menggunakan mesin pengering berputar (rotary).

2. Pendamping memberi beberapa contoh dalam pelatihan proses pembuatan mesin pengering berputar (rotary).

3. Pendamping memberi pengarahan sekaligus eksperimen penggunaan mesin pengering berputar (rotary).

\section{c. Tahapan Observasi}

1. Pada tahap observasi, kegiatan yang dilakukan pendamping adalah mengamati setiap tindakan peserta dalam bereksperimen dan melakukan ujian tertulis tentang pengetahuan yang telah dimiliki.

2. Pendamping bersama dengan peserta mendiskusikan permasalahan proses pengeringan berupa kualitas hasil pengeringan, waktu pengeringan dan bahan komponen pengeringan.

3. Pendamping kembali melakukan evaluasi secara tertulis terhadap tindakan yang telah dilakukan peserta.

4. Pendamping mengidentifikasi capaian yang diperoleh oleh peserta.

5. Pendamping melakukan evaluasi penyebab kekurangan yang terjadi saat pembuatan dan penggunaan mesin pengering dan merumuskan kembali cara memperbaiki hal-hal yang kurang berhasil.

\section{d. Tahapan Metode Pengumpulan Data Dan Analisa Data}


1. Pengumpulan data tentang proses yang dicapai menggunakan metode observasi dan wawancara.

2. Observasi dilakukan untuk mengamati keterampilan peserta secara individual.

3. Wawancara digunakan untuk mengetahui tanggapan peserta terhadap pengetahuan yang telah didapat. Data yang telah dikumpulkan akan dianalisa secara deskriptif dan presentase serta ditarik suatu kesimpulan secara umum.

\section{e. Pendampingan}

Tahapan kegiatan ini dimaksudkan untuk mematangkan kelompok mitra agar lebih fokus dalam pengeringan kopi robusta dan arabica yang merupakan kopi khas bengkulu serta pengeringan lada hitam terutama menyangkut pemecahan permasalahan yang ada pada mitra. Kegiatan ini dilakukan dengan cara tim PENERAPAN IPTEKS mendatangi kelompok mitra sebanyak 1 kali dalam sebulan untuk melihat, berkonsultasi, dan mengarahkan kelompok mitra jika dalam pelaksanaannya menemui hambatan.

\section{HASIL DAN PEMBAHASAN}

Pola pikir dan ketrampilan masyarakat di bidang pengeringan biji kopi dan lada hitam, ditingkatkan dengan pengenalan mesin pengering Rotary Dryer. Kegiatan yang telah dilakukan untuk mewujudkan itu yakni:

\section{Penyuluhan.}

Kegiatan penyuluhan dimaksudkan untuk membuka wawasan berpikir serta pengetahuan secara teori kepada peserta.

Materi penyuluhan diberikan secara tertulis kepada peserta. Setelah selesai penyampaian materi dilanjutkan dengan diskusi antar peserta dan narasumber. Kegiatan penyuluhan dihadiri oleh 30 orang peserta seperti ditunjukkan pada Gambar 4.
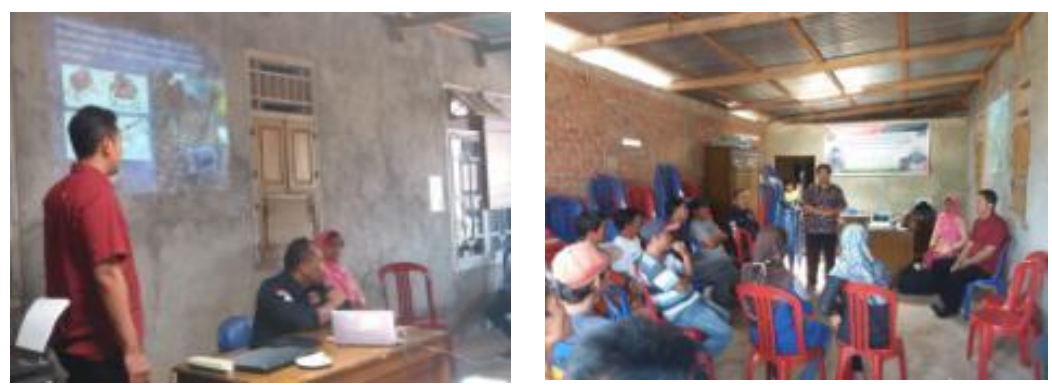

Gambar 4. Kegiatan Penyuluhan Mesin Pengering Berputar (rotary)

Kegiatan pelatihan ini telah berhasil merubah pola pikir masyarakat bahwa metode pengeringan dengan di jemur di alam terbuka ternyata memang kurang efektif dan menemui banyak kendala. Mereka sepakat jika pengering dengan mesin berputar lebih efektif dan memberi daya guna yang lebih baik.

\section{Pelatihan pembuatan dan pengujian Alat}

Kegiatan ini dilakukan oleh tim pengabdian dibantu mahasiswa serta disaksikan oleh peserta seperti ditunjukkan pada gambar 5. Kegiatan ini memberikan gambaran, petunjuk dan pemahaman secara lebih jelas tentang pemecahan persoalan proses pengeringan yang dihadapi oleh peserta.

Tahapan kegiatan pelatihan pembuatan dan pengujian alat yang dilakukan meliputi: 
1) Desain alat pengering berputar (rotary) dan cara menempatkan alat berdasarkan posisi yang tepat.

2) Pemilihan bahan drum pengering berputar (rotary) dari tong bekas

3) Menggunakan sistem kontrol mikrokontroler Arduino Uno.

4) Menggunakan tenaga surya sebagai penggerak sistem pemanas pada mesin berputar (rotary).
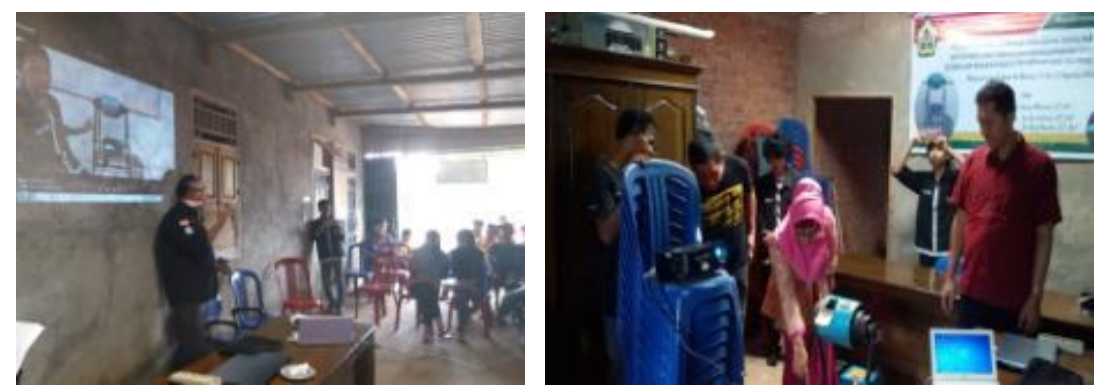

Gambar 5. Pelatihan Alat Pengering Berputar

Informasi yang dapat diperoleh pasca pelatihan ini adalah untuk desain alat sangat mudah dipahami sehingga memungkinkan untuk dilakukan. Pemilihan bahan untuk pembuatan mesin rotary tidak menjadi kendala.

\section{Pengujian Kemampuan Peserta Pelatihan.}

Kegiatan pelatihan dimaksudkan untuk mengetahui kemampuan peserta dan sekaligus menambah keterampilan mitra. Kegiatan pelatihan diawali dengan Pelatihan pengenalan komponen mesin pengering rotary yang dapat dilihat pada Gambar 6, seperti panel surya, drum pengeringan, pipa saluran udara panas, rangka/kontruksi, poros pemutar drum pengeringan dan sirip-sirip pengaduk.
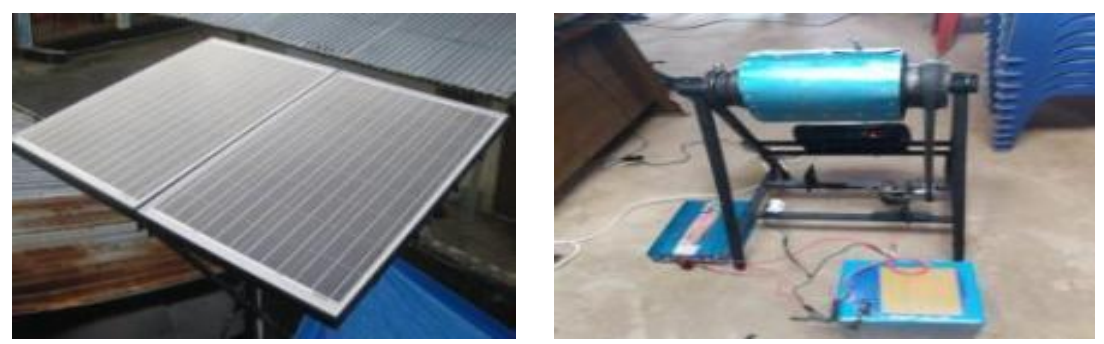

Gambar 6. Mesin Pengering Rotary, Kontroller dan Panel Surya

Kemudian dilanjutkan dengan pelatihan perancangan, pemilihan bahan dan pembuatan alat pengering hasil kebun berupa kopi dan lada hitam.

Prosedur pelatihan ini meliputi:

1. Perancangan, pemilihan bahan dan pembuatan mesin pengering rotary hasil perkebunan dan hasil hutan.

2. Pengujian mesin pengering rotary dengan pemaanfaatan hasil panen petani (kopi robusta dan arabica), lada hitam menggunakan filamen pemanas memanfaatkan energi angin melalui kincir angin. Foto tahapan pelaksanaan pelatihan dapat dilihat pada gambar 7 . 

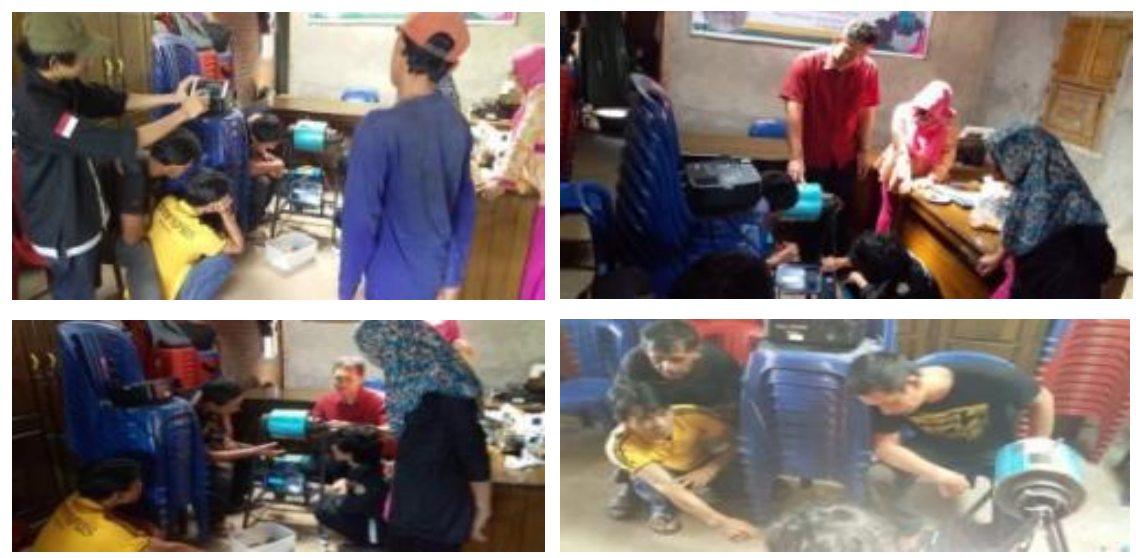

Gambar 7. Tahapan pelaksanaan pelatihan

Peserta pelatihan dibagi menjadi 4 kelompok, dengan perwakilan dari mereka (Jamak, Andi, Danwan, Lukman) masing masing melakukan uji coba alat. Tidak kalah antusiasnya peserta ibu-ibu (Deli) juga melakukan uji coba alat selama pelatihan. Hasil pelatihan ini mengindikasikan bahwa mereka setuju kalau alat pengering berputar ini cocok dan memungkinkan untuk dibuat.

Pengumpulan data tentang proses Observasi dilakukan untuk mengamati keterampilan peserta secara individual. Wawancara digunakan untuk mengetahui tanggapan peserta terhadap pengetahuan yang telah didapat. Data yang telah dikumpulkan akan dianalisa secara deskriptif dan presentase serta ditarik suatu kesimpulan secara umum. Hasil dari analisis data tersebut menunujukkan bahwa pola pikir masyarakat telah terbuka. Semula pengeringan biji kopi dengan metode dijemur langsung di halaman atau jalanan, kini mereka mulai faham bahwa hal tersebut kurang baik. Kelompok kerja yang terbentuk selama pelatihan ini cukup mengetahui komponen mesin pengering dan mengetahui penggunaan mesin pengering berputar (rotary) dalam menghasilkan produk kopi atau lada hitam kualitas tinggi dengan waktu pengeringan yang lebih singkat dan produk pengeringan yang higienis. Dengan demikian proses pembuatan mesin tersebut dapat berjalan dengan lancar.

\section{KESIMPULAN DAN SARAN}

\section{Kesimpulan}

1. Masyarakat peserta pelatihan mengetahui proses kerja mesin pengering rotari untuk mengolah hasil perkebunan kopi dan biji-bijian lainnya.

2. Masyarakat antusias dan memahami manfaat mesin pengering untuk mengolah hasil perkebunan kopi dan biji-bijian lainnya.

3. Pemahaman masyarakat akan waktu pengeringan dan kualitas pengeringan yang baik semakin meningkat.

\section{Saran}


1. Masyarakat meminta untuk kegiatan ini dilaksanakan rutin dalam rangka alih teknologi untuk proses pengolahan hasil kebunnya.

2. Untuk membantu masyarakat dalam mengenal jenis-jenis proses pengolahan hasil kebun lainnya.

\section{DAFTAR PUSTAKA}

Amali, L, M, K., Mohamad, Y., Harun, E, H., 2015, Karakteristik Potensi Energi Surya dan Energi Angin Pada Lahan Potensil Agropolitan yang Belum Dimanfaatkan, SETRUM - Volume 4, No. 2, Desember 2015.

Anonim, 2009, Sekam Padi Sebagai Sumber Energi Alternatif dalam Rumah Tangga Petani, http://www.litbang.deptan.go.id/artikel/one/210/pdf/Sekam-Juni.

Gunasekaran, K., Shanmugan, V., Suresh, P., 2012, Modelling and Analytical Experimental Study of Hybrid Solar Dryer Integrated with Biomass Dryer for Drying Coleus Forskohlii Stems, IPCSIT 28: 28-32.

Henderson, S, M., Perry, 1990, Agricultural Process Engineering, New York; John Willey and Sons, Ltd.

Hermawan, Y., 2009, Pemanfaatan Limbah Sekam Padi Sebagai Bahan Bakar Dalam Bentuk Briket, http://fisika.brawijaya.ac.id/bss-ub/proceeding/.

Nugraha, S., R, Rahmat, 2008, Energi Mahal, Manfaatkan Briket Arang Sekam, Warta Penelitian dan Pengambangan Pertanian Vol 30. No 4 thn 2008, Hal 1-2.

Putra, I, E., Hadi, P., 2013. Analisa Efisiensi Alat Pengering Tenaga Surya Tipe Terowong Berbantukan Kipas Angin Pada Proses Pengeringan Biji Kopi, Jurnal Teknik Mesin Vol. 3, No. 2, Oktober $2013: 22-25$.

Setiawan, Y., W, Eka, Sari., Wahyudi, I., Mustofa, A., 2016. Pengeringan Lada Pada Mesin Pengering Dengan Variasi Putaran Motor, Flywheel Jurnal Teknik Mesin Untirta Volume II Nomor 1, April 2016.

Sutrisno, dkk, 2006, Manajemen Pasca Panen Padi di Lahan Pasang Surut Sumatera Selatan untuk Mendapatkan Beras dan Benih Berkualitas, Balitpa Sukamandi.

Tambunan, A, H., Darmawan, I, W., 2017, Energi dan Teknologi untuk Pertanian Industrial Berkelanjutan, Penerbit IPB Press, IPB Science Park Taman Kencana, Kota Bogor - Indonesia, ISBN: 978-602-440-047-7 